\title{
Motivation of Saudi Arabia Tertiary Level Students Learning English as a Foreign Language
}

\author{
Abdullah Al Mamun Bhuiyan ${ }^{1}$
}

\begin{abstract}
This paper focuses on the motivation of Saudi Arabian students in learning English at the tertiary level. To show the significance of motivation, Gardner's socio-educational model of SLA was used. Focus was placed on government initiatives, parents' inspiration, classroom atmosphere, and teachers' inspirations at elementary and tertiary levels in English language learning. A questionnaire was used to collect data with an attitudinal scale and a demographic section. It was found that in general, participants believed English should be taught from grade one at the elementary level by qualified English teachers. In terms of motivation, it was found that family awareness plays a crucial role. It was also found that parents should care more about the language efficiency of their children rather than the grades They score in examinations.
\end{abstract}

Keywords: Motivation, English education, parents' inspiration, learning atmosphere, early education

\section{Introduction}

The Education system in Saudi Arabia has changed a lot during the past decade focusing more on becoming a 'knowledge based economy' (Faruk, 2014, p. 74). This is also reflected in the courntry's vision 2030. More emphasis is placed on vocational training, innovative advanced technologies, entrepreneurship, market needs and multi-faceted education.

\footnotetext{
${ }^{1}$ Lecturer, Department of English, Faculty of Languages and Translation, King Khalid University, Saudi Arabia, Email: mridul.kku@gmail.com
} 
The knowledge based economy requires that English language be mastered for coping with current globalized world. The ninth development plan (2010-2014) of Saudi Arabia has also clearly stated that "knowledge is available only in English not in Arabic" (Faruk, 2014, p. 177). At the policy level, Saudi connoisseurs have already realized that the more "the state moves toward the core-zone of world economy, the more English is needed" (Faruk, 2014, p. 177).

This distinctive situation is seen as a result of the economic and political interdependence between the Arab countries and the other nations of the world, which necessitated the Arab countries to acquire a linguistic access to the Western World in order to enter into business alliances with most of the English speaking countries (Ebrahim \& Awan, 2015, p. 194).

For this reason, special attention has been given to English education from elementary to tertiary level in Saudi Arabia. Many universities and other agencies in Saudi Arabia including the Ministry of Education, have shown keen interest in providing opportunities for learning the English language (Ebrahim \& Awan, 2015, p. 194).

In terms of policy, budget allocation and infrastructure development, the changes are satisfactory. For instance "the government is increasing the expenditure of the education market by an average $12 \%$ per year since 2007 " (Euromonitor, 2013, para. 4). Nevertheless, students' impression and attitudes towards English language learning are not up to the mark.

Moreover, in spite of increasing the budget of the education sector every year, the level of achievement in learning English as a foreign language is far below (Rahman \& Alhaisoni, 2013, p. 114). Recent studies have found that "Saudi learners of English see no link between their efforts and the desired goal" (Al-Seghayer, 2014, p. 14). They learn English just to pass in the exam as it is a required subject. At school, most students study English just to fulfill formalities. On the other hand, students get "weak encouragement and support from parents" (as cited in Al-Seghayer, 2014, p. 19). Most of the students at university think "English is a dry and boring subject" (Al-Seghayer, 2014, p. 19). This paper, therefore, explored the motivation of Saudi Arabian students learning English as a foreign language. Mainly, the focus is on the motivation of university level students. A questionnaire was used to explore students' opinions. Data were collected from five different colleges (two male and three female colleges) of King Khalid University and Bisha University. 


\section{The Education system in Saudi Arabia}

The founder of Saudi Arabia, the late King Abdul Aziz, had a vision of focusing on education as a means of development from the very beginning. (Mohammed, 2013). He gave his instructions to establish new schools and institutes and encouraged book publishing (Ministry of Foreign Affairs, 2015). Later on, formal education was started in 1922 (Alkhazim, 2003, p. 480). The Ministry of Education was established in 1953 and the Ministry of higher Education was established in 1975 (Rahman \& Alhaisoni, 2013, p. 112-113). Under the Ministry of Education there are now forty-two educational districts throughout the Kingdom (Oyaid, 2009).

The Saudi education system is divided into four stages, namely: 6 years of elementary education, 3 years intermediate education, 3 years secondary education, and 4 or 5 years tertiary education. The academic year is divided into two semesters of eighteen weeks each. Sixteen weeks are for teaching and two weeks for examinations.

Education in Saudi Arabia is segregated by sex and divided into three separately administered systems: general education for boys, education for girls, and traditional Islamic education (for boys) (Sedgwick, 2001). Currently, there are a total of 34,749 schools with a total of 5,187,498 students from KG to secondary level (Mohammed, 2013). A tertiary level, there are 53 public and private universities in Saudi Arabia (Classbase, 2016).

According to the Ministry of Higher Education, there were 757,770 students enrolled in Saudi universities in 2009-2010. Over 120,000 Saudi students are currently sponsored by the Saudi government to undertake higher education outside the Kingdom. Briefly we can say that education in Saudi Arabia has four defining characteristics, namely a focus on teaching of Islam, a centralized system of control and education support, state funding, and a general policy for general segregation (Smith \& Abouammoh, 2013)

\section{Background of English education in Saudi Arabia}

Teaching of English as a foreign language was introduced into the Saudi education system in 1924 (Faruk, 2014, p. 176). Till today, English is the only foreign language taught in Saudi public schools. It is taught as a compulsory subject from grade six to the university level. However, Ministry of Education is planning to introduce it in grade four (Rahman \& Alhaisoni, 2013, p. 113).

At the university level, English was introduced in 1949 in Mecca, and the first English Language Department being at King Saud University in 1957 (Faruk, 2014, p.176). Intermediate and secondary students are taught English is 
four 45-minute class periods per week. Sixth grade elementary students receive only two 90-minute class periods of English instruction per week (Al-Seghayer, 2014, p. 19).

Classroom instruction is largely dominated by teachers. Students' responses are very few in English classes. Teachers focus on the development of grammatical competency with only marginal attention paid to communicative competency and discourse (Al-Seghayer, 2014, p. 22).

Every year the government spends billions dollars for English teachers' recruitment, language labs, curriculum development and teachers' training (Rahman \& Alhaisoni, 2013, p. 114). They offer attractive packages along with all the fringe benefits to the employees to get the maximum output from them (Shabbir \& Bughio, 2009, p.75).

\section{General objectives of teaching English in Saudi Arabia}

Article No. 50 of the Saudi education policy has emphasized learning another language in addition to Arabic. Students with the knowledge of at least one of the living languages, in addition to their own mother tongue language, will be able to acquire knowledge and sciences from other communities and to participate in the service of Islam and humanity (Liton, 2012, p. 23). In terms of living languages, Saudi Arabia gives importance on English. The English department in the Directorate of Curriculum at the Ministry of Education held that English education should foster students' ability to comprehend and express basic English (Nalliveettil, 2014, p. 33).

Amjaad (2013) mentioned general objectives of teaching English of Saudi Arabian students. They are:

1. Develop the students' intellectual, personal and professional abilities.

2. Acquire a level of proficiency in language skills (listening, speaking, reading and writing) that enables them to communicate with speakers of English.

3. Acquire the linguistic competence necessarily required in various life situations.

4. Acquire the linguistic competence required in different professions.

5. Develop their awareness of the importance of English as a means of international communication. 
6. Develop positive attitudes towards learning English.

7. Develop the linguistic competence that enables them to be aware of the cultural, economical, and social issues of their society in order to contribute in giving solutions.

8. Develop the linguistic competence that enables them, in the future, to present and explain Islamic concepts and issues, and participate in spreading Islam.

9. Develop the linguistic competence that enables them, in the future, to present the culture and civilization of their nation.

10. Benefit from English-speaking nations, in order to enhance the concept of international cooperation that develop understanding and respect of cultural differences among nations.

11. Acquire the linguistic bases that enable them to participate in transferring scientific and technological advances of other nations to their nation.

12. Acquire the linguistic bases that enable them to present and explain Islamic concepts and issues, and participate in different Islamic programs.

\section{Students' motivation in learning English}

Both intrinsic and extrinsic motivations are important in second language learning. If the students are not motivated individually, socially and academically, whatever method or policy you choose will be ineffective. Concerning motivation Al-Zubeiry (n.d., p. 15) says that

lack of motivation on the part of language learners may lead to a situation where learners do not show interest in learning the target language. Such a situation is likely to affect the learners' success in learning the language. A number of research scholars indicate that motivation is considered as a key factor that influences the rate and success of second/foreign language learning.

It is a fact that second language learning is time consuming and requires hard work. In Saudi Arabia, it is much more challenging as people do not find any use of English in their day to day life. Moreover, in the job sector Arabic is still the dominant language -all official documents are written in Arabic. Interestingly, most of the employees do not know even simple English as it is not useful for official purposes. Most of the times they are reluctant to learn English. 
The impact of this is visible in tertiary education too. At tertiary level, most of the students are not intrinsically motivated. They think that teachers will always externally motivate them as they do not get any link between English and their desired jobs. Most of the times their efforts are devoted to acquiring the minimal competency needed to pass to the next grade level and pay no attention to other of learning (Al-Seghayer, 2014, p. 18). Some students only come to the exam hall to get the pass mark; most of the times they do not take English exams seriously.

Moreover, a considerable number of Saudi students believe that learning English is beyond their reach (Al-Seghayer, 2014, p. 19). Most of them are not internally and externally motivated to learn English.

\section{Parents' idea about English language learning in Saudi Arabia}

The parents' role as an important factor in children's education is applicable to learning a new language. Regarding parents' role AlQahtani and Zumor (2016, p. 20) says that parents' involvement in their children's education is essential for successful proficiency in both languages, the mother tongue and the second one.

Studies have found that children have a better foreign language achievement if their parents have an active attitude towards this foreign language even if these parents do not speak the language. Parents can show their positive attitudes towards the learning of a foreign language by being a part of their child's learning at home and at school (as cited in Alhussein \& Milian, n.d., p. 2).

In Saudi Arabia most of the times parents show positive attitude towards English language learning because they realize that their children should learn English as it is the language of prestige. In spite of such positivity, parents just look at whether their children passed and got good grades in the exam or not. They are not worried about children's English language efficiency. They are cozened by a pre-defined idea that passing in the exam resembles knowing good English. Sometimes parents request concerned teachers to help their children with minimum grade in English courses.

\section{The present study}

This study aimed to find out Saudi Arabian English department students' motivation in learning English at the tertiary level. It tried to answer the 
following research question: what are the factors which are influencing Saudi Arabian students in learning English?

\section{Methods}

The study used quantitative data analysis and the results are intended to provide numerical analysis. Data were collected from Department of English of King Khalid University and Bisha University - in total 178 students participated in the study. The questionnaire was completed by English department students from King Khalid University, Saudi Arabia in the academic year 1435-36 H.

The attitudinal scale is used with close-ended questions on a four points Likert scale. The questionnaire has two parts - first part is based on students' intension of learning English language in relation to their social, academic and job perspective--twelve questions are used here. Second part consists of eight questions and it tries to find out how much time students spend in learning English in different situations. The researcher tabulates the data and represents the data graphically to enable a clearer representation and easier analysis.

The items in the questionnaire were as follows:

\section{Part 1: Students' Intention of Learning English}

1. You got enough exposure to learn English language at school level.

2. You got sufficient number of qualified teachers for teaching English at school.

3. Your teachers at school encouraged you to speak in English.

4. English should be taught in school from elementary level.

5. You get interest in learning English.

6. English is a difficult language to learn.

7. Practice will help you to learn good English.

8. Learning English is important to get job in Saudi Arabia.

9. You have sufficient number of qualified teachers to teach English at University.

10. In school, teachers emphasized on free hand writing in English. 
11. In University, teachers emphasize on free hand writing in English.

12. Your teachers at university encourage you to speak in English in the classroom.

\section{Part 2: Time Spent for Learning English in Different Situations}

1.You read English story books, newspapers etc.

2. You watch English TV channels regularly.

3. You feel interested in speaking English inside and outside the class room.

4. Your teachers at University encourage you to speak in English.

5. Your parents encourage you to learn English as a foreign language.

6. You speak in English outside the classroom with your friends.

7. You speak in English with your family members.

8. You speak in English in public places.

\section{Results and Discussion}

\section{Students' Intention of Learning English}

Students' intension of learning English based on social, academic and job perspective has been given below (Figure 1). There are twelve questions in this part and each question has four options. All options are mentioned in percentage. 


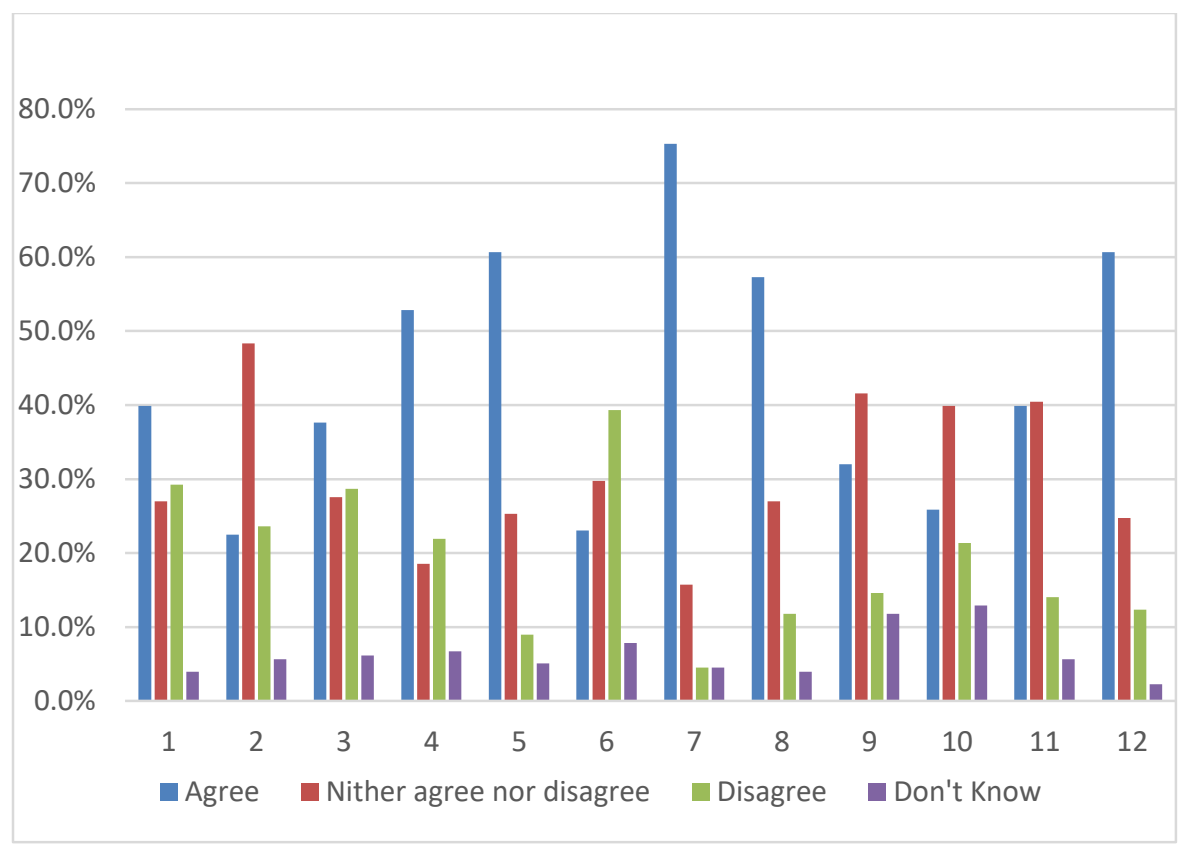

Figure 1: Students' intention of learning English based on social, academic and job perspective

For question no.1, $40 \%$ students opined that they got enough exposure to learning English. However, in terms of quality of English teachers only 22\% students gave positive response (question 2). We can say that English teaching and teachers' quality are sub-standard at school.

For question 4 , it was found that almost $53 \%$ of the students agreed with the idea that English should be taught from grade one because almost $61 \%$ students (question 5) were interested in learning English.

In response to question 6, $40 \%$ of the students opined that English is not a difficult language, while $23 \%$ students agreed that it is. Here $75 \%$ of students agreed that they need more exposure and practice to increase their English language efficiency (question 7). Almost 58\% agreed that they need English to get a job in Saudi Arabia (question 8).

For question $10,30 \%$ of the students agreed that they had qualified teachers at university, while, only $14.6 \%$ of the students raised questions about 
the qualification of their teachers. Almost $42 \%$ students take the neutral position. This could imply two things: firstly, most of the English department teachers are foreigners who speak in English. Since most of the students do not understand English perfectly, there must be a communication gap between teachers and students. For this reason, most of the students could not come to a conclusion in the survey whether the teacher were good or bad in terms of knowledge and teaching.

In response to question number 11 and 12, students held that $26 \%$ teachers emphasize on free hand writing. However, at the tertiary level $40 \%$ teachers emphasize on free hand writing. The concomitant result of this is the dramatic improvement of the few students who did not have satisfactory English writing exposure before entering university. This shows that if teachers at school give importance on more freehand writing in English, students can improve English writing efficiency. It also indicates that the more time students spend in English language learning, the more quickly they master it.

Similar results were generated spoken English too. Since most of the English teachers at the university are foreigners, they inspire students to speak in English. In the survey it was found that almost $61 \%$ teachers inspire students to speak in English (question 12). This shows that sometimes reinforcement and compulsion can help motivate students in learning a language.

\section{Time Spent for Learning English in Different Situations}

Students' time spent in English language learning in different situations are given below (Figure 2). There were eight questions in this part and each question had four options. All responses are mentioned in percentage. 


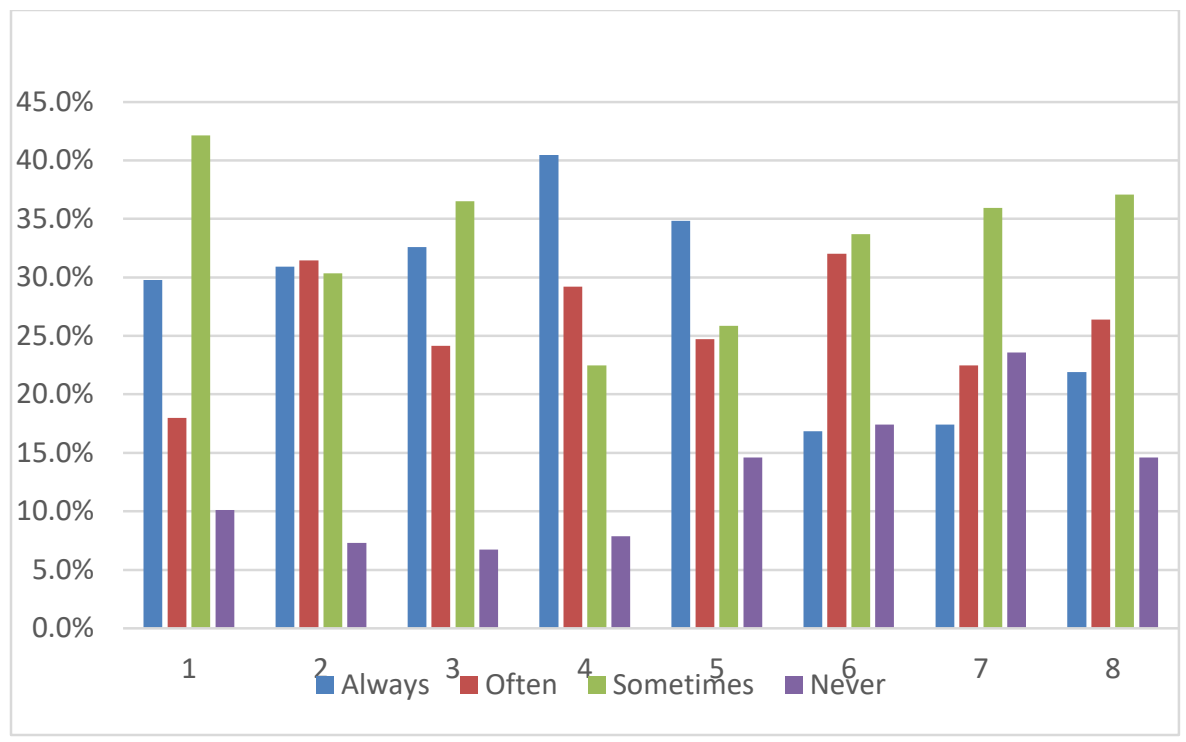

Figure 2 Students' time spent in English language learning in different situations are given below

For question 2, it was found that 31\% students liked to watch English TV channels (mostly English movies). Here 32\% students gave mixed opinions. If we add both responses, we can come to a conclusion that more or less $63 \%$ students like to watch English TV channels or movies. On the other hand, in case of reading books or newspapers in English (question 1) only 29\% students said that they always read. This could be because they face difficulties in reading while they do not face the same problem in watching English TV channels or movies. This demonstrates that Saudi students prefer audio visual materials to books and related materials in practicing English as they have poor English background.

In response to Question 3, that $36.5 \%$ of the students agreed that not always like to speak in English, while $32.6 \%$ of the students had a positive opinion. Though students have poor back ground, almost $41 \%$ students try to speak in English inside and outside the class room as their teachers inspire them at university (question-4).

Question-5 specifies that parents also play a key role in learning a language; 35\% parents always encourage their children to learn English. 24\% parents often do this. Only about $14 \%$ of the parents never encourage their children in learning English. It shows the changing mentality of parents in learning English in Saudi Arabia. 
We see a disappointing scenario in using English outside the class room. Almost 34\% students do not use English outside the class room; only $17 \%$ students use English outside the classroom (question-6). It shows that outside the classroom Saudi students get little opportunity to use and practice English. We see the same scenario at home which is the best place to practice English outside the class room. It shows that only $17 \%$ students always use English with their family members (question-7). Here the support of the family plays a crucial role in using and learning English. We see almost same result for using English in public places like restaurants, shopping malls etc. Here, only $22 \%$ students always like to use English in public places (question-8). Therefore, students should get more opportunities and spend more time to overcome the school phase shortcomings at tertiary level.

\section{Conclusions and Recommendations}

Recruitment of more Saudi Arabian teachers. Motivation has a connection culture, society and mental acquaintance. The motivational component is influenced to some extent by factors that affect an individual's willingness to accept foreign behavior patterns (Gardner \& Lalonde, 1985, p. 1). Saudi Arabian students do not get the mental support for accepting foreign behavior patterns as most of the English department teachers are foreigners; student and teacher do not understand each other as cultural and mental gaps always remain there. Moreover, language difference deepens the complexity because most of the students enter university with little English. It is already proved that in second language learning mother tongue helps a lot for better understanding which most of the foreign teachers are not able to do here. As a result of this bitter experience from the very first moments students lose their motivation and interest in learning English. They fear English; they start believing that it is a difficult language. Regarding discomfort and fear of students Garner (1985) in his socioeducational model says that "the combination of effort plus desire to achieve the goal of learning the language plus favorable attitudes toward learning the language" is important for second language learning. Therefore, Saudi authority should recruit more Saudi Arabian teachers for English language teaching. Local teachers can at least understand the level of their students and general problems of their students than anyone else.

Culture oriented learning materials. Saudi language experts should come up with their own English language learning materials. Most of the times it is found that students do not understand the context of a listening or reading extract as the topic is based on another culture. Culture oriented materials will instigate students inspiration and interest about English language. 
Students should be serious. According to Gardner's socio-educational model, for a student to be considered motivated four elements of a goal, desire to achieve the goal, positive attitudes, and effort are necessary (as cited in Taie \& Afshari, 2015, p. 607). It is a big problem as Saudi students show lack of desire and seriousness in learning English as they do not know the goal of learning English. They give priority to course completion than learning this language as there is a little use of English in the job sector. Most of the students do not show sincerity even in exam also. They think about a minimum grade in English courses. Here it has connection with the policy level decisions of the government of the country. They should make a standard that for getting some specific jobs, students should have minimum $\mathrm{C}$ grade in all English courses at university.

Efficient English teachers at elementary and secondary levels. Saudi government should recruit efficient English teachers for schools because strong base and early learning are very important for second language learning. Saudi Arabia is investing a lot in English education at tertiary level to be a leading developed country within 2030. However, it is revealed from the survey that Saudi government should focus on English education at school level. If they need to recruit teachers from other counties, they should collect efficient teachers for elementary and secondary levels. Moreover, they should start English education from class one. It is already proved that experience is one of crucial affective factor in second language learning. It is so pathetic to see a student at tertiary level without minimum English background. Therefore, students should get ample opportunity and experience to reduce their anxiety level. Besides, we cannot expect motivation from students at tertiary who do not have minimum English education. It is already proved that motivation has a connection with confidence, knowledge and encouragement. Motivation will emerge automatically with adequate knowledge and confidence. Besides, students will be motivated to learn English if they get sufficient number of qualified teachers at elementary and secondary.

\section{References}

Alhussein, M. A., \& Milian, M. (n.d.). Saudi parents' attitude towards their children learning English as a second language in the United States. Retrieved from: http://webcache.googleusercontent.com/search?q=cache:veYv8zUue7 EJ:faculty.ksu.edu.sa/23734/Thsis/Thesis.doc $+\& c d=4 \&$ hl $=$ en $\& c t=c l n$ $\mathrm{k} \& \mathrm{gl}=\mathrm{sa}$ 
Alkhazim, M. A. (2003). Higher education in Saudi Arabia: Challenges, solutions, and opportunities missed. Higher Education Policy, 16, 479-486.

Al-Qahtani, Z., \&Zumor, A. W. A. (2016). Saudi Parents' attitude towards using English as a medium of instruction in private primary schools. International Journal of Applied Linguistics \& English Literature, 5 (1), 18-32.

Al-Zubeiry, H.Y.A. (n.d.) The socio-psychological orientations Saudi learners of English as a foreign language. Makkah, Saudi Arabia: Umm AlQura University. Retrieved from: https://uqu.edu.sa/files2/tiny_mce/plugins/filemanager/files/4280212/ AR-8--5.pdf

Amjaad. M. H. (2013, January 13). General objectives of teaching English in Saudi Arabia. Retrieved from: https://supvamjaad.wordpress.com/2013/01/13/general-objectives-ofteaching-english-in-saudi-arabia/

Al-Seghayer, K. (2014). The four most common constraints affecting English teaching in Saudi Arabia. International Journal of English Linguistics, 4 (5), $17-26$

Classbase. (2016, April 1). Universities in Saudi Arabia. Retrieved from: http://www.classbase.com/countries/saudi-arabia/Universities

Ebrahim, M. I., \& Awan, N. A. (2015). Second language acquisition in Arab Learners: A paradigm shift. International Journal of Languages, Literature and Linguistics, 1(3), 193-197.

Euromonitor International 2014. (May, 2013). Education in Saudi Arabia. www. euromonitor.com

Faruk, S. M. G. (2014). Saudis' attitude towards English. Professional Communication and Translation Studies, 7 (1-2), 173-180.

Gardner, R. C., Lalonde, R. N., \& Pierson, R. (1983). The socio-educational model of second language acquisition: An investigation using Lisrel causal modeling, Journal of Language and Social Psychology, 2(1), 115. doi: 10.1177/0261927X8300200101.

Gardner, R. C. (1985). Social psychology and second language learning: The role of attitude and motivation, 10. London: Edward Arnold. 
Liton, H. A. (2012). Developing EFL teaching and learning practices in Saudi colleges: a review. International Journal of Instruction, 5 (2), 129152 .

Ministry of Foreign Affairs. (2015, December 5). King Abdul Aziz bin Abdur Rahman Al-Faisal Al Saud. Retrieved from: http://www.mofa.gov.sa/sites/mofaen/ServicesAndInformation/about KingDom/SaudiArabiaKings/Pages/KingAbulAziz.aspx

Mohammed, I. (2013, January 2). Kingdom tops world in education spending. Arab News. Retrieved from: http://www.arabnews.com/saudiarabia/kingdom-tops-world-education-spending

Nalliveettil, G. M. (2014). Assessing EFL graduates in communicative language teaching classroom. Arab World English Journal, 5 (2), 24-37.

Oyaid, A. A. (2009). Education policy in Saudi Arabia and its relation to secondary school teachers' ICT use, perceptions, and views of the future of ICT in education. Retrieved from: https://ore.exeter.ac.uk/repository/bitstream/handle/10036/69537/Oy aidA.doc.pdf?sequence $=2$

Rahman, M. M. U., \& Alhaisoni, E. (2013). Teaching English in Saudi Arabia: prospects and challenges. Academic Research International, 4 (1), 112-118.

Sedgwick, R. (2001, November 1). Education in Saudi Arabia. World Education News and Reviews. Retrieved from http://wenr.wes.org/2001/11/wenr-nov-dec-2001-education-in-saudiarabia/

Shabbir, B., \&Bughio, M. Q. (2009). Factors affecting the language learning process among Saudi students. International Research Journal of Arts \& Humanities, 37, 75-81.

Smith, L., \&Abouammoh, A. (2013). Higher education in Saudi Arabia: Reforms, challenges and priorities. In L. Smith, \& A. Abouammoh (Eds.), Higher Education in Saudi Arabia Achievements, Challenges and Opportunities (pp. 1-12). New York: Springer.

Taie, M. \& Afshari. A (2015). A Critical Review on the Socio-educational Model of SLA. Theory and Practice in Language Studies, 5 (3), 605612. London: Academy Publication. 